\title{
Glycine nitrogen in total parenteral nutrition: two prospective clinical trials comparing the efficacy of high and low glycine containing amino acid solutions
}

\author{
R G P Rees, J J Payne James, G K Grimble, D Halliday, P G Frost, D B A Silk
}

\begin{abstract}
Glycine has been regarded as a poor source of nitrogen for total parenteral nutrition. Two prospective randomised cross over controlled clinical trials were undertaken to compare the efficacy of high and low glycine containing amino acid solutions in parenterally fed malnourished hypoalbuminaemic patients with gastrointestinal disease. In the first study $(n=9)$, amino acid solutions in which glycine accounted for $23 \%$ and $4 \%$ of total nitrogen were compared. No statistically significant difference was found in urea nitrogen/total urinary nitrogen excretion (mean (SEM) 83.4 (1.4) v $81.6(1 \cdot 7) \%, p=0.31)$, nitrogen balance $(-1.9(2.4) v-0.6(2.0) \mathrm{g} /$ day, $\mathrm{p}=0.31)$ or plasma protein concentrations and blood urea nitrogen. In the second extended study $(n=5)$, there was no significant difference in net whole body protein synthesis $(+1.3(4 \cdot 7) v-0.2(3.7)$ $\mathrm{mg} / \mathrm{kg} / \mathrm{hour}, \mathrm{p}=0.69)$ or fractional $(0.403$ $(0.070) v 0.480(0.41) \% /$ hour, $\mathrm{p}=0.68)$ and absolute albumin synthesis rates $(6.0(0.9) v$ $7 \cdot 2(0.06) \mathrm{mg} / \mathrm{kg} / \mathrm{hour}, \mathrm{p}=0.22)$, on comparing solutions of $25 \%$ and $8 \%$ glycine nitrogen. In addition, a significantly higher proportion of total urinary nitrogen comprised urea when patients received the low glycine containing amino acid source $(81.4(2.5)$ v $83.8(3.2) \%$, $\mathbf{p}=0.04)$. It is concluded that there are no apparent short term nutritional or metabolic disadvantages to using amino acid solutions that contain up to $25 \%$ of nitrogen as glycine in total parenteral nutrition.
\end{abstract}

Department of Gastroenterology and Nutrition, Central Middlesex Hospital, London

R G P Rees

J J Payne James

G K Grimble

P G Frost

D B A Silk

Clinical Nutrition

Research Group, Clinical

Research Centre, Harrow D Halliday

Correspondence to:

Dr D B A Silk, Department of Gastroenterology and Nutrition, Central Middlesex Hospital, Acton Lane, London NW10 7NS.

Accepted for publication 21 October 1991
Nitrogen balance and blood aminograms have indicated that in both hypercatabolic and postoperative patients amino acid solutions are best formulated according to the known requirements of the normal growing child. ${ }^{67}$ These in turn are comparable with the amino acid pattern of egg or human milk protein where glycine represents less than $4 \%$ of total nitrogen. ${ }^{2 \times}$ In keeping with this thinking, it has been concluded that solutions containing large amounts of glycine, as a non-essential nitrogen source, are not suitable for $\mathrm{TPN}^{2}$ and, in fact, not cost effective. $^{3}$

Additional arguments against using significant amounts of glycine as a nitrogen source in TPN arise from several findings. Thus, it has been reported that glycine turnover is limited to 200 $\mathrm{mg} / \mathrm{kg} / \mathrm{day}^{9}$ and that important renal losses of glycine occur during parenteral feeding with glycine rich solutions. ${ }^{25}$ In one study, nitrogen balance in patients fed with high glycine containing formulations was not significantly more positive than that in unfed controls. ' Hyperammonaemia in infants has also been associated with feeding a TPN solution relatively high in glycine $(27 \%){ }^{10}$ Associated toxicity problems were, however, corrected by the administration of additional arginine. Finally, one theoretical objection to including large amounts of glycine in TPN amino acid solutions relates to the suggestion of Jackson and Golden" that, metabolically, glycine (along with serine, threonine, histidine, and lysine) should be considered a 'deaminating' amino acid. This supposes that with high intakes of glycine its amino nitrogen is predominantly incorporated into urea rather than contributing to protein synthesis via transamination reactions in the precursor amino acid pool.

In deference to the above arguments, there is evidence available that favours the enrichment of the non-essential amino acid component of TPN nitrogen solutions with glycine. There are data from neonates, ${ }^{12}$ children, ${ }^{13}$ and severely ill parenterally fed patients ${ }^{14}$ suggesting that endogenous synthesis of glycine may be limiting during periods of rapid growth or increased tissue turnover. Glycine also participates in the synthesis of purines and glutathione and is important in detoxication reactions and in the formation of creatine..$^{15}$ Compared with other amino acids, glycine is relatively well cleared from the plasma pool in both 'well' and 'sick' patients. ${ }^{4}$ Finally, clinical trials have shown the efficacy of a TPN amino acid solution in which glycine accounted for $23 \%$ of total nitrogen content (equal to that of alanine).

Impressed with the clinical data supporting the use of glycine supplements in TPN amino 
acid solutions and mindful that cost effectiveness in clinical practice is becoming a major issue, we have sought to re-examine the role of glycine in meeting nitrogen requirements during TPN. Two prospective double blind controlled clinical trials were designed in which commercially available amino acid solutions, differing mainly in the amount of glycine they contained, were compared in respect of nitrogen metabolism and protein synthesis in malnourished hypoalbuminaemic gastrointestinal patients requiring TPN.

\section{Methods}

\section{STUDY I}

\section{Patients}

Nine patients with gastrointestinal disease who were hypoalbuminaemic and either malnourished or nutritionally 'at risk', and who required TPN as the sole means of nutritional support, were entered into the study (Table I). Patient weight and height were used to calculate the body mass index (BMI). Measurements were also made of triceps skinfold thickness and mid-arm circumference. ${ }^{16}$ Seven patients had recently undergone surgery and all were hypoalbuminaemic. All patients were clinically stable and without cardiac or renal failure, diabetes mellitus, or any sign of sepsis when studied. None was on a ventilator and none required any special medication or received any blood or blood products during the study period. No patient underwent any surgical procedure during the study. The catabolic state of individual patients, as assessed by total urinary nitrogen losses, varied according to the severity of the underlying illness and the extent of any initial surgery.

\section{Experimental design}

Patients were maintained in fluid balance with normal $4 \%$ glucose and $0 \cdot 18 \%$ sodium chloride solution ( $320 \mathrm{kcal} /$ day) before parenteral feeding was begun via a subclavian vein feeding catheter. Surgical patients were fed from the third postoperative day. Patients were randomised, according to numbered envelopes containing random numbers, to receive 31 of one of two isonitrogenous and isocaloric nutritive solutions daily in a prospective double blind five day cross over controlled trial. Except for their amino acid sources, the two solutions were kept as similar as possible in composition. Nutritive solutions were administered using the 'all in one' 31 bag technique with 24 hour pump controlled infusion. ${ }^{17}$ The compositions of the two nutritive solutions are summarised in Table II. Each solution supplied $14 \mathrm{~g}$ of amino acid nitrogen and $2200 \mathrm{kcal}$ of non-protein energy as a $45 \% / 55 \%$ mixture of lipid (20\% Intralipid, KabiVitrum Ltd, Uxbridge, Middlesex, UK) and 20\% glucose. The 31 bags also contained recommended daily allowances of vitamins and trace elements. Continuous 24 hour urine collections,

TABLE I Details of patients studied on randomisation

\begin{tabular}{|c|c|c|c|c|c|c|c|c|}
\hline Patient & Sex & Age & $\begin{array}{l}\text { Weight } \\
(\mathrm{kg})\end{array}$ & $\begin{array}{l}\text { Body } \\
\text { mass } \\
\text { index }\end{array}$ & $\begin{array}{l}\text { Triceps } \\
\text { skinfold } \\
\text { indext }\end{array}$ & $\begin{array}{l}\text { Mid arm } \\
\text { circumference }\end{array}$ & $\begin{array}{l}\text { Plasma } \\
\text { albumin } \delta \\
(\mathrm{g} / \mathrm{l})\end{array}$ & Diagnosis \\
\hline \multicolumn{9}{|l|}{ Study I: } \\
\hline $1^{\star \star}$ & M & 57 & 74 & $23 \cdot 6$ & $10 \cdot 8$ & $26 \cdot 0$ & 20 & Laparotomy (perforated duodenal ulcer) \\
\hline 2 & $\mathrm{~F}$ & 65 & 38 & $15 \cdot 3$ & $4 \cdot 2$ & $24 \cdot 0$ & 21 & Colectomy (Crohn's disease) \\
\hline $3^{\star}$ & $\mathbf{F}$ & 50 & 46 & $16 \cdot 9$ & $7 \cdot 0$ & $25 \cdot 0$ & 30 & Choledochojejunostomy (benign common bile duct stricture) \\
\hline 4 & $M$ & 27 & 76 & $23 \cdot 4$ & $4 \cdot 5$ & $26 \cdot 0$ & 22 & Laparotomy (acute necrotising pancreatitis) \\
\hline & $M$ & 52 & 59 & $20 \cdot 4$ & $5 \cdot 6$ & $26 \cdot 5$ & 32 & Subtotal gastrectomy (carcinoma) \\
\hline 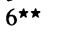 & $M$ & 62 & 78 & $24 \cdot 1$ & $8 \cdot 6$ & $27 \cdot 0$ & 26 & Acute pancreatitis \\
\hline 7 & $\mathrm{~F}$ & 37 & 52 & $20 \cdot 3$ & $12 \cdot 5$ & $22 \cdot 7$ & 30 & Laparotomy (perforated duodenal ulcer) \\
\hline & M & 50 & 70 & $22 \cdot 8$ & $12 \cdot 4$ & $27 \cdot 2$ & 34 & Laparotomy (acute necrotising pancreatitis) \\
\hline $9 \star 9^{\star \star}$ & $\mathrm{F}$ & 42 & 36 & $15 \cdot 0$ & $9 \cdot 0$ & $22 \cdot 0$ & 32 & Perforated oesophagus \\
\hline \multicolumn{9}{|c|}{ Study II: } \\
\hline 1 & $M$ & 43 & 68 & $22 \cdot 2$ & $10 \cdot 8$ & $26 \cdot 8$ & 23 & Laparotomy (perforated appendix) \\
\hline & $M$ & 26 & 52 & $16 \cdot 6$ & $4 \cdot 8$ & $23 \cdot 8$ & 29 & Hemicolectomy (Crohn's colitis) \\
\hline $3^{\star \star}$ & $M$ & 76 & 66 & $22 \cdot 3$ & $10 \cdot 9$ & $26 \cdot 2$ & 23 & Abdomino-perineal resection (rectal carcinoma) \\
\hline $4 \star \star \star$ & $\mathrm{F}$ & 70 & 39 & $14 \cdot 9$ & $4 \cdot 4$ & $17 \cdot 6$ & 33 & Radiation enteritis \\
\hline 5 & M & 58 & 61 & $19 \cdot 9$ & $5 \cdot 0$ & $25 \cdot 0$ & 31 & Laparotomy (acute pancreatitis) \\
\hline
\end{tabular}

*Body mass index $\left(\mathrm{wt} / \mathrm{ht}^{2}\right)<20=$ significantly malnourished.

†Triceps skinfold thickness (men 7.5-11·3, women 9.3-14.9 mm (60-90\% adult reference standard value).

$\ddagger$ Mid arm circumference (men $17 \cdot 6-26 \cdot 3 \mathrm{~cm}$, women $17 \cdot 1-25 \cdot 7 \mathrm{~cm}(60-90 \%$ adult reference standard value).

§Lower limit of normal range $-35 \mathrm{~g} / \mathrm{l}$.

$\star \star$ Begun with high glycine TPN

TABLE II Main nutrients infused daily with the test nitrogen

sources (per 3 l bag)

\begin{tabular}{|c|c|c|c|c|}
\hline & \multicolumn{2}{|l|}{ Study I } & \multicolumn{2}{|l|}{ Study II } \\
\hline & Solution A & Solution B & Solution A & Solution B \\
\hline Nitrogen (g) & 14 (high glycine) & 14 (low glycine) & 14 (high glycine) & 14 (low glycine) \\
\hline Glucose $20 \%(\mathrm{~g})$ & 300 & 300 & 250 & 250 \\
\hline $50 \%$ & - & - & 100 & 100 \\
\hline Intralipid $20 \%(\mathrm{~g})$ & 100 & 100 & 100 & 100 \\
\hline Sodium $(\mathrm{mmol})$ & 73 & 75 & 100 & 104 \\
\hline Potassium (mmol) & 90 & 90 & 90 & 92 \\
\hline Calcium (mmol) & $5 \cdot 0$ & $7 \cdot 5$ & 10 & 10 \\
\hline Magnesium (mmol) & $6 \cdot 5$ & $3 \cdot 8$ & $6 \cdot 5$ & $9 \cdot 5$ \\
\hline Phosphate (mmol) & 30 & 40 & 40 & 40 \\
\hline Non-protein energy (kcal) & 2200 & 2200 & 2400 & 2400 \\
\hline Non-protein energy: nitrogen ratio $(\mathrm{kcal} / \mathrm{g})$ & $157: 1$ & $157: 1$ & $171: 1$ & $171: 1$ \\
\hline Volume (1) & $3 \cdot 0$ & $3 \cdot 0$ & $2 \cdot 5$ & $2 \cdot 5$ \\
\hline
\end{tabular}


using $10 \%$ thymol in isopropanol as a preservative, were made for all patients throughout the study. Patients were monitored daily for blood glucose and on alternative days for electrolytes, urea, and liver function parameters throughout the study. No patient required insulin for control of blood glucose.

\section{Composition of the amino acid mixtures}

The two parenteral nitrogen sources were commercially prepared solutions of crystalline Lamino acids, in which the glycine content was either high (Synthamin 14: old formulation, Travenol Laboratories Ltd, Thetford, Norfolk UK) or low (Vamin N, KabiVitrum Ltd) (Table III). In Synthamin 14, glycine accounted for $23 \%$ of total nitrogen, while in Vamin $N$ this proportion amounted to only $4 \%$. Both nitrogen sources contained all of the essential amino acids, which were, with the exception of L-methionine and L-arginine, present in greater quantities in Vamin N. It can also be seen that while Vamin N contained all of the non-essential amino acids, Synthamin 14 contained more alanine and lacked the non-essential amino acids aspartic acid, cysteine, glutamic acid, and serine.

\section{Analysis of urine and measurement of nitrogen balance}

Aliquots of urine were refrigerated at $4^{\circ} \mathrm{C}$ and analysed within 48 hours for urea using an automated urease assay (Astra 4, Automated Stat/Routine Analyser with Beckman Conductivity Electrode, Beckman-RIIC Ltd, High Wycombe, Bucks, UK) and total nitrogen using an automated chemiluminescence nitrogen analyser (Antek Model 703C Chemiluminescence Nitrogen System, Edect Scientific Ltd, Hargrave, Northants, UK). ${ }^{18}$ Total urinary nitrogen and the proportion excreted as urea nitrogen were determined for each study day. The mean daily nitrogen balance for each patient was then determined from nitrogen actually infused and total urinary nitrogen excreted. Nitrogen balances were corrected for changes in blood urea nitrogen (BUN) during the last three days of each study period, using an estimated space distribution of urea of $60 \%$ body weight. ${ }^{19}$

\section{Measurement of plasma protein concentrations \\ On day 5 of each study period, $5 \mathrm{ml}$ of venous blood were collected into lithium heparin tubes, centrifuged, and the plasma stored at $-20^{\circ} \mathrm{C}$ before analysis for albumin, transferrin, and thyroxine binding prealbumin in within patient batches. Plasma protein concentrations were measured using the technique of rate nephelo- metry (Beckman Automated Immunochemistry System, ICS Analyser II, High Wycombe, Bucks, UK).}

\section{STUDY II}

\section{Patients}

A further five hypoalbuminemic and poorly nourished patients with gastrointestinal disease, who required TPN as the sole means of nutritional support, were studied (Table I). Four patients had recently undergone surgery. The fifth patient had radiation induced enteritis and had been unable to tolerate enteral feeding because of diarrhoea. Patients were moderately hypercatabolic, as assessed by urinary nitrogen losses. All were clinically and metabolically stable without any organ failure and did not undergo any surgery while studied.

\section{Experimental design}

Patients were parenterally fed in a randomised five day cross over study as previously described. All had been maintained in fluid balance with hypocaloric glucose alone for at least three days before beginning 2.51 of isonitrogenous and isocaloric parenteral diet containing either a high or low glycine amino acid nitrogen source. Complete nutritive solutions contained $14 \mathrm{~g}$ nitrogen and $2400 \mathrm{kcal}$ of non-protein energy as a $42 / 58 \%$ lipid/glucose mixture. Their compositions are summarised in Table II. Patient monitoring and measurement of urinary nitrogen balance, urinary urea, and plasma protein concentrations were as in study $\mathrm{I}$.

\section{Composition of the amino acid mixtures}

The two commercial amino acid solutions compared in this study were Aminofusin L Forte (Pfrimmer Co, Erlangen, West Germany) and Vamin 14 (KabiVitrum Ltd). It can be seen in Table III, that while both nitrogen sources were again complete in essential amino acids, greater quantities were universally present in Vamin 14, representing $64.6 \%$ of total nitrogen compared with $41.1 \%$ in Aminofusin $\mathrm{L}$ forte. Glycine, however, comprised $25 \%$ of nitrogen in Aminofusin $\mathrm{L}$ forte, but only $8 \%$ in Vamin 14 . In addition, Aminofusin L Forte contained an incomplete range of non-essential amino acids, lacking aspartic acid, cysteine, serine, and tyrosine.

\section{Measurement of whole body protein turnover}

On day 5 of each nutritive regimen, starting at 9 am, whole body protein turnover was measured in each patient using a primed constant infusion of $\mathrm{L}-\left(1-^{13}\right) \mathrm{C}$ leucine. ${ }^{20}$ Before each infusion, a bolus injection of $\mathrm{L}-\left(1-^{13}\right) \mathrm{C}$ leucine $(0.5 \mathrm{mg} / \mathrm{kg})$ and labelled bicarbonate $(0.09 \mathrm{mg} / \mathrm{kg})$ were given to prime the relevant pools. Both ${ }^{13} \mathrm{C}$ labelled tracers (99\%) were obtained from Cambridge Isotope Laboratories (Cambridge, MA, USA). The infusion of $\mathrm{L}-\left(1^{-13}\right) \mathrm{C}$ leucine $(0.55 \mathrm{mg} / \mathrm{kg} /$ hour $)$ was then continued for 6 hours. Once a plateau had been established (after 90 minutes), samples of plasma and expired air were taken every 30 minutes. Expired air was collected into a specially adapted urine bag and immediately transferred to a vacutainer (Becton Dickinson, Rutherford, NJ, USA) for storage. Simultaneous measurements of the carbon dioxide production rate were made from infrared absorbance of expired air using an indirect calorimeter. Plasma enrichment of ( $\left.{ }^{13} \mathrm{C}\right)$ ketoisocaproate, rather than leucine, was used to 
determine flux as ketoisocaproate is produced intracellularly from leucine and has been found, for both muscle and liver, to be closer to the metabolic pool from which leucine is removed by protein synthesis and oxidation than plasma leucine. ${ }^{21}{ }^{22}$ Enrichment in plasma of $\left({ }^{13} \mathrm{C}\right)-$ ketoisocaproate was determined using the quinoxalinol-trimethylsilyl derivative and gas chromatography mass spectrometry. ${ }^{23}$. The isotopic enrichment of expired air carbon dioxide was measured in an isotope ratio mass spectrometer. ${ }^{2+}$ From the measurement of leucine flux and oxidation, leucine incorporation into and release from protein was then calculated from the relationship: $Q=S+C=B+I$ where $Q$ is the rate of leucine turnover (flux); $S$, the rate of leucine incorporation into protein (synthesis); C, the rate of leucine oxidation (catabolism); B, the rate of leucine release from protein (breakdown); and $I$, the rate of exogenous leucine intake. Values for leucine parameters were converted to corresponding estimates of whole body protein turnover by using the constant $590 \mu \mathrm{mol}$ leucine/g protein ${ }^{-1} \cdot{ }^{20}$

\section{Measurement of albumin synthesis rates}

The fractional synthesis rate (FSR) of plasma

TABLE III Composition of the amino acid mixtures (mmol amino acid nitrogen per $14 \mathrm{~g}$ nitrogen)

\begin{tabular}{|c|c|c|c|c|}
\hline & \multicolumn{2}{|l|}{ Study I } & \multicolumn{2}{|l|}{ Study II } \\
\hline & $\begin{array}{l}\text { Solution A } \\
\text { (Synthamin 14- } \\
\text { old formulation) }\end{array}$ & $\begin{array}{l}\text { Solution B } \\
(\operatorname{Vamin} N)\end{array}$ & $\begin{array}{l}\text { Solution A } \\
\text { (Aminofusin } \\
\text { L Forte) }\end{array}$ & $\begin{array}{l}\text { Solution B } \\
\text { (Vamin 14) }\end{array}$ \\
\hline $\begin{array}{l}\text { Essential: } \\
\text { L-isoleucine } \\
\text { L-leucine } \\
\text { L-lysine } \\
\text { L-methionine } \\
\text { L-phenylalanine } \\
\text { L-threonine } \\
\text { L-tryptophan } \\
\text { L-valine } \\
\text { L-arginine } \\
\text { L-histidine }\end{array}$ & $\begin{array}{r}30.3 \\
39.2 \\
65.9 \\
32.3 \\
31.2 \\
29.3 \\
14.6 \\
32.6 \\
197 \cdot 8 \\
70.4\end{array}$ & $\begin{array}{r}44 \cdot 3 \\
60 \cdot 2 \\
79 \cdot 5 \\
19.0 \\
49.6 \\
37 \cdot 5 \\
14.6 \\
54.7 \\
112.9 \\
69.1\end{array}$ & $\begin{array}{r}21.3 \\
30.5 \\
62.9 \\
25.5 \\
24.2 \\
15.1 \\
7.8 \\
23.0 \\
169.0 \\
35.6\end{array}$ & $\begin{array}{r}32.8 \\
46.5 \\
96.5 \\
28 \cdot 8 \\
36.9 \\
36.1 \\
13.6 \\
48.6 \\
200 \cdot 0 \\
102.2\end{array}$ \\
\hline $\begin{array}{l}\text { Non-essential: } \\
\text { L-alanine } \\
\text { L-aspartic acid } \\
\text { L-cysteine } \\
\text { L-glutamic acid } \\
\text { Glycine } \\
\text { L-proline } \\
\text { L-serine } \\
\text { L-tyrosine }\end{array}$ & $\begin{array}{c}193.4 \\
- \\
- \\
\overline{2} \\
22.5 \\
30.3 \\
- \\
1.8\end{array}$ & $\begin{array}{r}50 \cdot 2 \\
45 \cdot 9 \\
17 \cdot 2 \\
91 \cdot 1 \\
41 \cdot 7 \\
104 \cdot 9 \\
106 \cdot 3 \\
4 \cdot 1\end{array}$ & $\begin{array}{l}123 \cdot 5 \\
- \\
- \\
112 \cdot 6 \\
245 \cdot 1 \\
112 \cdot 0 \\
- \\
-\end{array}$ & $\begin{array}{r}139 \cdot 2 \\
19 \cdot 5 \\
2 \cdot 2 \\
29 \cdot 0 \\
81 \cdot 2 \\
46 \cdot 0 \\
33 \cdot 3 \\
1 \cdot 0\end{array}$ \\
\hline
\end{tabular}

TABLE IV Total urea urinary nitrogen $(N)$ excretion and nitrogen balance (corrected for blood urea nitrogen) during the last three days of each feeding regimen

\begin{tabular}{|c|c|c|c|c|c|c|}
\hline \multirow[b]{2}{*}{ Patient } & \multicolumn{3}{|l|}{ Solution $A$} & \multicolumn{3}{|l|}{ Solution B } \\
\hline & $\begin{array}{l}\text { Total urinary } \\
N(g / d)\end{array}$ & $\begin{array}{l}\text { Urea } N \\
\text { (\%) total) }\end{array}$ & $\begin{array}{l}\text { N balance } \\
(\mathrm{g} / \mathrm{d})\end{array}$ & $\begin{array}{l}\text { Total urinary } \\
N(g / d)\end{array}$ & $\begin{array}{l}\text { Urea } N \\
\text { (\% total) }\end{array}$ & $\begin{array}{l}\text { N balance } \\
(\mathrm{g} / \mathrm{d})\end{array}$ \\
\hline $\begin{array}{l}\text { Study I: } \\
1 \\
2 \\
3 \\
4 \\
5 \\
6 \\
7 \\
8 \\
9 \\
\text { Mean (SEM) } \\
\text { Study II: }\end{array}$ & $\begin{array}{l}12 \cdot 0 \\
9 \cdot 2 \\
15 \cdot 9 \\
21 \cdot 9 \\
10 \cdot 5 \\
31 \cdot 0 \\
19 \cdot 1 \\
15 \cdot 8 \\
8 \cdot 0 \\
15 \cdot 9(2 \cdot 4)\end{array}$ & $\begin{array}{l}77 \cdot 9 \\
85 \cdot 2 \\
76 \cdot 4 \\
87 \cdot 7 \\
85 \cdot 4 \\
83 \cdot 5 \\
89 \cdot 3 \\
81 \cdot 2 \\
84 \cdot 0 \\
83 \cdot 4(1 \cdot 4)\end{array}$ & $\begin{array}{l}+2.3 \\
+5.1 \\
-1.9 \\
-8.1 \\
+3.4 \\
-17.0 \\
-5.0 \\
-1.8 \\
+5.9 \\
-1.9(2.4)\end{array}$ & $\begin{array}{l}13 \cdot 5 \\
6 \cdot 8 \\
12 \cdot 2 \\
22 \cdot 8 \\
11.9 \\
22 \cdot 7 \\
17 \cdot 8 \\
16 \cdot 4 \\
7 \cdot 3 \\
14 \cdot 6(1 \cdot 9)^{\star}\end{array}$ & $\begin{array}{l}69 \cdot 9 \\
85 \cdot 2 \\
85 \cdot 5 \\
82 \cdot 2 \\
80 \cdot 6 \\
86 \cdot 2 \\
80 \cdot 8 \\
78 \cdot 0 \\
86 \cdot 1 \\
81 \cdot 6(1 \cdot 7) \dagger\end{array}$ & $\begin{array}{l}+0.6 \\
+7 \cdot 3 \\
+1 \cdot 7 \\
-8 \cdot 7 \\
+2 \cdot 2 \\
-8 \cdot 8 \\
-4 \cdot 0 \\
-2 \cdot 3 \\
+6 \cdot 7 \\
-0.6(2 \cdot 0) \ddagger\end{array}$ \\
\hline $\begin{array}{l}1 \\
2 \\
3 \\
4 \\
5 \\
\text { Mean (SEM) }\end{array}$ & $\begin{array}{l}13 \cdot 1 \\
14 \cdot 4 \\
8 \cdot 6 \\
12 \cdot 3 \\
13 \cdot 3 \\
12 \cdot 3(1 \cdot 0)\end{array}$ & $\begin{array}{l}86 \cdot 8 \\
86 \cdot 1 \\
73 \cdot 0 \\
81 \cdot 8 \\
79 \cdot 3 \\
81 \cdot 4(2 \cdot 5)\end{array}$ & $\begin{array}{l}+0.6 \\
-0.6 \\
+5.1 \\
+1.7 \\
+0.4 \\
+1.4(1 \cdot 0)\end{array}$ & $\begin{array}{l}14 \cdot 9 \\
16 \cdot 2 \\
12 \cdot 7 \\
10 \cdot 3 \\
11 \cdot 2 \\
13 \cdot 1(1 \cdot 1) \$\end{array}$ & $\begin{array}{l}90 \cdot 8 \\
89 \cdot 9 \\
73 \cdot 3 \\
84 \cdot 6 \\
80 \cdot 3 \\
83 \cdot 8(3 \cdot 2) 9\end{array}$ & $\begin{array}{l}-1.4 \\
-2.6 \\
+0.8 \\
+3.5 \\
+2.5 \\
+0.6(1.1)^{\star}\end{array}$ \\
\hline
\end{tabular}

${ }^{\star} \mathrm{p}=0.25 ; \mathrm{fp}=0.31 ; \neq \mathrm{p}=0.31 ;\left\lceil\mathrm{p}=0.88 ; \Uparrow \mathrm{p}=0.04 ;{ }^{\star} \mathrm{p}=0.51\right.$ albumin was determined in an identical manner to that described and discussed by Pacy et al. ${ }^{25}$

Plasma enrichment at plateau of $\left({ }^{13} \mathrm{C}\right)$ ketoisocaproate, measured during the last four hours of the whole body protein turnover studies, was taken to represent the enrichment of the intrahepatic precursor pool. Blood samples were taken every 30 minutes. Albumin was separated from plasma $(1 \mathrm{ml})$ using trichloracetic acid in methanol and then subjected to procedures for enrichment determination by isotope ratio mass spectrometry, as described previously. ${ }^{26}$ From the best fit line of the linear incorporation of $\mathrm{L}-\left({ }^{13} \mathrm{C}\right)$ leucine into albumin, during the period of plateau $\left({ }^{13} \mathrm{C}\right)$-ketoisocaproate enrichment, the FSR of plasma albumin (\%/hour) was calculated as follows:

$\stackrel{\left({ }^{\prime \prime} \mathrm{C}\right) \text { leucine enrichment at } 6 \text { hours }-\left({ }^{\circ} \mathrm{C}\right) \text { leucine enrichment at } 2 \text { hours }}{ } \times 100$ plasma plateau (' $\left({ }^{\prime} \mathrm{C}\right) \alpha-\mathrm{KIC}$ enrichment $\times 4$ hours

The absolute synthesis rate (ASR) of albumin was, in turn, determined by multiplying the FSR by the intravascular albumin mass. In order to calculate the latter, plasma volume was determined for each patient on both study days by a dilution technique of injecting intravenously, $5 \mu \mathrm{Ci}$ of iodinated ( $\left.{ }^{125} \mathrm{I}\right)$ human albumin (Amersham International plc, Amersham, Bucks, UK) and taking serial $8 \mathrm{ml}$ blood samples from +15 to +60 minutes from a contralateral vein. ${ }^{27}$ The intravascular albumin mass was used for computing the ASR of albumin as, during the four hour period taken for measuring FSR, little ${ }^{13} \mathrm{C}$ leucine labelled albumin would have exchanged with the extravascular albumin pool. ${ }^{28}$

\section{STATISTICS}

Paired data from both studies were compared for statistical significance using the non-parametric Wilcoxon test for matched pairs.

\section{Results}

STUDY I

Urinary nitrogen excretion and nitrogen balance Paired data for mean daily total urinary nitrogen excretion, urea nitrogen as a proportion of total urinary nitrogen, and nitrogen balance for each patient studied are shown in Table IV. Five patients were hypercatabolic with total urinary nitrogen losses in excess of $15 \mathrm{~g} / \mathrm{day}$. The highest urinary nitrogen losses were recorded in patients with acute pancreatitis (with haemorrhage and necrosis) (patients 4 and 6) and in one with peritonitis caused by a perforated duodenal ulcer (patient 7). There was no statistically significant difference between any of the parameters studied for the last three days of each study period.

\section{Plasma protein concentrations and BUN}

There was no significant difference in the level of either plasma albumin, transferrin, or thyroxine binding prealbumin on day 5 of each study period (Table V). Concentrations of these 
plasma proteins remained low with either TPN nitrogen source. There was also no significant difference in the corresponding level of BUN.

\section{STUDY II}

Urinary nitrogen excretion and nitrogen balance Patients in the second study represented a less catabolic group than in the first, with positive nitrogen balance being achieved in 3 of the 5 patients while fed either nitrogen source (Table IV). The mean daily nitrogen balance was also positive in both instances, without any statistically significant difference between high and low glycine containing solutions. The proportion of total urinary nitrogen excreted as urea was significantly lower with the high glycine containing amino acid solution compared with the low glycine solution $(p=0.04)$.

\section{Plasma protein concentrations and BUN}

As in the first study, there was no significant difference between either the concentration of any of the plasma proteins or the BUN on day 5 of feeding the two nitrogen sources (Table V).

\section{Whole body protein turnover}

Data for whole body protein synthesis and breakdown obtained on day 5 of each feeding

TABLE V Plasma protein and blood urea nitrogen (BUN) concentrations on day 5 of each feeding regimen (mean (SEM))

\begin{tabular}{|c|c|c|c|c|c|c|}
\hline & \multicolumn{3}{|l|}{ Study I } & \multicolumn{3}{|l|}{ Study II } \\
\hline & Solution A & Solution B & $p$ & Solution $A$ & Solution B & $p$ \\
\hline Albumin $(\mathrm{g} / \mathrm{l})(35 \cdot 0)^{\star}$ & $28 \cdot 2(1 \cdot 6)$ & $27 \cdot 9(1 \cdot 8)$ & 0.68 & $28 \cdot 4(2 \cdot 1)$ & $27 \cdot 2(1 \cdot 7)$ & 0.50 \\
\hline Transferrin $(g / l)(2 \cdot 0)^{\star}$ & $2 \cdot 0(0 \cdot 2)$ & $2 \cdot 2(0 \cdot 1)$ & $0 \cdot 21$ & $1.9(0.2)$ & $1.6(0 \cdot 1)$ & 0.65 \\
\hline $\begin{array}{l}\text { Thyroxine binding prealbumin } \\
(\mathrm{mg} / \mathrm{l})^{\star}(260) \\
\text { BUN }(\mathrm{mmol} / \mathrm{l})\end{array}$ & $\begin{array}{l}148(24) \\
14 \cdot 0(2 \cdot 2)\end{array}$ & $\begin{array}{c}151(23) \\
12 \cdot 2(1 \cdot 2)\end{array}$ & $\begin{array}{l}0 \cdot 90 \\
0 \cdot 18\end{array}$ & $\begin{array}{l}201(31) \\
9.8(1.0)\end{array}$ & $\begin{array}{l}184(28) \\
10 \cdot 4(0.8)\end{array}$ & $\begin{array}{l}0.57 \\
0.59\end{array}$ \\
\hline $\mathrm{BUN}(\mathrm{mmol} / \mathrm{l})$ & $14 \cdot 0(2 \cdot 2)$ & $12 \cdot 2(1 \cdot 2)$ & $0 \cdot 18$ & $9 \cdot 8(1 \cdot 0)$ & $10 \cdot 4(0 \cdot 8)$ & 0.59 \\
\hline
\end{tabular}

${ }^{\star}$ Lower limit of normal range.

TABLE VI Whole body protein turnover on day 5 of each feeding regimen ( $\mathrm{mg} / \mathrm{kg} / \mathrm{hour}$ ) in study II

\begin{tabular}{|c|c|c|c|c|}
\hline \multirow[b]{2}{*}{ Patient } & \multicolumn{2}{|l|}{ Solution A } & \multicolumn{2}{|l|}{ Solution B } \\
\hline & $\begin{array}{l}\text { Protein } \\
\text { synthesis }\end{array}$ & $\begin{array}{l}\text { Protein } \\
\text { breakdown }\end{array}$ & $\begin{array}{l}\text { Protein } \\
\text { synthesis }\end{array}$ & $\begin{array}{l}\text { Protein } \\
\text { breakdown }\end{array}$ \\
\hline $\begin{array}{l}1 \\
2 \\
3 \\
4 \\
5 \\
\text { Mean (SEM) }\end{array}$ & $\begin{array}{l}153 \cdot 2 \\
135 \cdot 1 \\
204 \cdot 8 \\
194 \cdot 4 \\
186 \cdot 4 \\
174 \cdot 8(13 \cdot 2)\end{array}$ & $\begin{array}{l}144 \cdot 2 \\
149 \cdot 7 \\
193 \cdot 9 \\
197 \cdot 6 \\
181 \cdot 9 \\
173 \cdot 5(11 \cdot 2)\end{array}$ & $\begin{array}{l}202 \cdot 0 \\
157 \cdot 6 \\
199 \cdot 7 \\
195 \cdot 1 \\
156 \cdot 8 \\
182 \cdot 2(10 \cdot 2)^{\star}\end{array}$ & $\begin{array}{l}212 \cdot 2 \\
177 \cdot 6 \\
189 \cdot 3 \\
200 \cdot 0 \\
151 \cdot 2 \\
186 \cdot 1(10 \cdot 4) \dagger\end{array}$ \\
\hline
\end{tabular}

${ }^{\star} \mathrm{p}=0.68 ; \mathrm{p}=0.68$.

TABLE VII Fractional and absolute albumin synthesis rates on day 5 of each feeding regimen in study II

\begin{tabular}{|c|c|c|c|c|}
\hline \multirow[b]{2}{*}{ Patient } & \multicolumn{2}{|l|}{ Solution A } & \multicolumn{2}{|l|}{ Solution B } \\
\hline & $\begin{array}{l}\text { Fractional } \\
\text { synthesis rate } \\
(\% / h)\end{array}$ & $\begin{array}{l}\text { Absolute } \\
\text { synthesis rate } \\
(\mathrm{mg} / \mathrm{kg} / \mathrm{h})\end{array}$ & $\begin{array}{l}\text { Fractional } \\
\text { synthesis rate } \\
(\% / h)\end{array}$ & $\begin{array}{l}\text { Absolute } \\
\text { synthesis } \\
(\mathrm{mg} / \mathrm{kg} / \mathrm{h})\end{array}$ \\
\hline $\begin{array}{l}1 \\
2 \\
3 \\
4 \\
5 \\
\text { Mean (SEM) }\end{array}$ & $\begin{array}{l}0.228 \\
0.525 \\
0.567 \\
0.448 \\
0 \cdot 248 \\
0.403(0.070)\end{array}$ & $\begin{array}{l}3 \cdot 1 \\
8 \cdot 0 \\
6 \cdot 5 \\
7 \cdot 2 \\
5 \cdot 1 \\
6 \cdot 0(0 \cdot 9)\end{array}$ & $\begin{array}{l}0.539 \\
0.494 \\
0.564 \\
0.327 \\
0.475 \\
0.480(0.041)^{\star}\end{array}$ & $\begin{array}{l}6 \cdot 7 \\
8 \cdot 2 \\
6 \cdot 9 \\
5 \cdot 4 \\
8 \cdot 8 \\
7 \cdot 2(0 \cdot 6) \dagger\end{array}$ \\
\hline
\end{tabular}

${ }^{\star} \mathrm{p}=0.68 ; \mathrm{tp}=0 \cdot 22$ regimen for each patient are given in Table VI. Differences in mean values for synthesis and breakdown with high and low glycine containing formulations were not significant. The value for mean net protein synthesis (synthesis - breakdown) was, as for nitrogen balance, higher for the glycine enriched compared with the low glycine containing solution. The respective values were mean $(\mathrm{SEM})+1 \cdot 3(4 \cdot 7) v-0 \cdot 2(3 \cdot 7)$ $\mathrm{mg} / \mathrm{kg} /$ hour. This difference was, however, not significant $(p=0 \cdot 69)$.

\section{Fractional and absolute albumin synthesis rates}

Paired values for albumin FSR and ASR are given in Table VII. They show a considerable range for patients 1,4 , and 5 but there was clearly no difference between the high and low glycine containing nitrogen sources studied for either measurement.

\section{Discussion}

These two complementary randomised cross over clinical trials in the routine feeding of mainly hypercatabolic patients compared the efficacy of commercially available amino acid solutions; one of the major differences in amino acid content being their glycine content. The results indicate that within the time scale of the experimental protocols, there were no apparent nutritional or metabolic disadvantages to using in TPN the two amino acid solutions that contained substantial amounts of glycine (up to $25 \%$ of total nitrogen content). Although Tweedle et $a l^{2}$ found that positive nitrogen balance was not achieved in postoperative patients fed parenterally with solutions containing $26 \%$ and $70 \%$ of total amino acid nitrogen as glycine, other workers have found no disadvantage when glycine accounted for $11 \%^{24}$ and $23 \%$ ? of total parenteral nitrogen given to hypermetabolic patients. Furthermore, Steinhardt et $a l^{31}$ were able to maintain a comparable positive nitrogen balance in young baboons, when growth promoting oral nutrition was followed by parenteral nutrition supplying nitrogen as either free amino acids or synthetic dipeptides, each containing a glycine molar equivalent of $50 \%$. It should be emphasised, however, that these animals were healthy and not metabolically stressed. The results of the first study, showing no significant difference between the high and low glycine containing amino acid solutions with regard to urinary nitrogen excretion, nitrogen balance, plasma protein, and BUN concentration data, prompted the design of the further more detailed study.

In the second study, in addition to the above, we were able to measure whole body protein turnover and albumin synthesis rates. We judged that these indices would provide a more sensitive means of detecting any nutritional difference between the high and low glycine containing TPN solutions. However, with the exception of a lower percentage urinary nitrogen excretion on feeding the high glycine solution, there was again no statistically significant difference between TPN solutions in any of the parameters measured. 
Patients in both studies were mainly hypercatabolic, and the prescribed daily allowance of $14 \mathrm{~g}$ nitrogen (approximately $240 \mathrm{mg}$ nitrogen/ $\mathrm{kg} /$ day) was judged from previous work of ours ${ }^{31}$ and others, ${ }^{32}$ to be the least required for nitrogen balance in this type of patient. Mean nitrogen balance remained negative in the first study and just positive in the second, and there was little day to day variation in total urinary nitrogen excretion (CV 3.7 to 10.6 and 6.4 to 11.3 for studies I and II respectively). Thus, the experimental design of both studies should have permitted the sensitive measurement of patient response to the quality of nitrogen infused. It has been shown that nutrient withdrawal causes a reduction in whole body protein synthesis of between $30 \%$ and $40 \%$ in preoperative patients, ${ }^{33}$ and that, in general, amino acid supply is a major controlling factor in the rate of hepatic albumin synthesis. ${ }^{3+36}$ If, therefore, glycine nitrogen had been poorly available for tissue synthesis, but channelled directly into urea, this should have been reflected in the direct and indirect parameters of nitrogen utilisation measured in the two studies. In fact, in study II the proportional urea urinary nitrogen excretion was significantly less when patients were fed the high glycine nitrogen source compared with that low in glycine (Table IV, $\mathrm{p}=0.04$ ).

However, it is important to point out that apart from glycine content, there were other differences in both essential and non-essential amino acid composition between the amino acid solutions compared in the two studies (Table III). As stated earlier, with the exception of Lmethionine and $\mathrm{L}$-arginine in study $\mathrm{I}$, the levels of essential amino acids, including the relatively expensive branched chain leucine, isoleucine, and valine, were higher in the low glycine containing preparations. Therefore, any influence on the efficacy of nitrogen utilisation that was dependent on essential amino acid differences rather than glycine intake would have been expected to have advantaged the low glycine containing solutions. Both high glycine containing solutions had an incomplete range of non-essential amino acids with an excess of either alanine or glutamic acid in old formulation Synthamin and Aminofusion L Forte respectively. Alanine and glutamate have both been shown to play a central role in transamination reactions $\mathrm{s}^{37}$ and do not, therefore, represent the theoretical disadvantage as suppliers of nitrogen as the deaminating amino acid glycine." These two amino acids were also well represented in the Vamin preparations. Therefore, notwithstanding these limitations to the experimental design, the major variation in the concentration of glycine, if nutritionally significant, should have resulted in a measurable difference in the utilisation of the paired nitrogen sources studied.

The conclusion supported by the current studies together with previous experimental evidence, ${ }^{79}{ }^{20}$ namely that a high glycine content may not be deleterious to the efficacy of amino acid solutions for TPN is, we suggest, of practical importance as well as of theoretical interest. Amino acid solutions for TPN require, as for oral nutrition, a complete range of the essential amino acids and their cost remains high. Historically, the first commercially prepared solutions of synthetic amino acids, in addition to containing large proportions of glycine as an economic source of nonessential amino acid nitrogen, often consisted of unphysiological racemic mixtures of $\mathrm{D}$ - and $\mathrm{L}$ amino acids. ${ }^{38}$ Hence subsequent reformulation of most amino acid solutions to contain much less glycine and to correspond closely to the amino acid pattern of egg or human milk protein, on the grounds that this would improve nitrogen retention, may not have been justified. ${ }^{2}$

In addition to the potential cost advantage, there seem to be further considerations to the use of glycine as a nitrogen source in TPN. Firstly, as stated above, there is experimental work with neonates, ${ }^{12}$ children, ${ }^{13}$ and sick patients receiving TPN,$^{1+}$ that glycine may act as a conditionally limiting amino acid where metabolic demand for glycine exceeds endogenous synthesis. Secondly, support for the use of glycine in TPN has come from extensive preliminary work on the possible role of peptides in improving the nitrogen source of parenteral solutions. In addition to their relative cheapness to synthesise, Adibi $^{39}$ has observed that glycyl nitrogenterminal dipeptides are an efficiently utilised source of nitrogen in experimental animals.

We conclude, therefore, that these two controlled clinical trials suggest that, at least in the short term, glycine nitrogen may be efficiently utilised in sick patients requiring nutritional support and that its content need not reduce the efficacy and, therefore, cost effectiveness of nitrogen solutions for TPN.

The authors gratefully acknowledge the kind financial contribution made to this research by E Merk Ltd and KabiVitrum Ltd.

$1 \mathrm{FAO} / \mathrm{WHO} / \mathrm{UNU}$. Energy and protein requirements. Tech Rept Ser No 724. Geneva: World Health Organization, 1985

2 Tweedle DEF. Intravenous amino acid solutions. Br f Hosp Med 1975; 13: 81-92.

3 Anonymous. Adult parenteral nutrition: which preparations? Drug Ther Bull 1980; 18: 85-8.

4 Kingsnorth AN, Ross BD, Kettlewell M. Cost-effective parenteral feeding. Lancet 1980; ii: 1371 .

5 Batestone GF, Gent AE, Shakespeare PG. Cost-effective parenteral feeding. Lancet 1981 ; i: 225-6.

6 Anderson GH, Patel DG, Jeejeebhoy KN. Design and evaluation by nitrogen balance and blood aminograms of an amino acid mixture for total parenteral nutrition of adults with acid mixture for total parenteral nutrition of adults

7 Caldwell MD, O'Neill JA, Meng HC, Stahlman MH. Evaluation of a new amino acid source for use in parenteral nutrition. Ann Surg 1977; 185: 153-61

8 Jacobson S. Serum concentrations and urinary excretion of amino acids during total parenteral nutrition after abdominal surgery. $\mathcal{F}$ Parent Ent Nutr 1982; 6: 204-13.

9 Dolif D, Jürgens P. Untersuchungen über den Stickstoffhaushalt bei parenteraler Ernahrung. Z Emahrungswiss $1971 ; 10$ (suppl): 24

10 Heird WC, Nicholson JF, Driscoll JM, Schullinger JN, Winters RW. Hyperammonemia resulting from intravenous alimentation using a mixture of synthetic $\mathrm{L}$-amino acids. $\mathcal{f}$ Pediatr 1972; 81: 162-5.

11 Jackson AA, Golden MHN. ('N) Glycine metabolism in normal man: the metabolic amino-nitrogen pool. Clin Sci normal man: the

12 Panteliadis C, Jürgens $P$, Dolif D. Aminosäurenbedarf Frühund Neugeborener unter den Bedingungen der parenteralen Ernährung. Infusionsther Klin Ermäehr 1975; 2: 65-72.

13 Persaud C, Forrester T, Jackson AA. Glycine: limiting amino acid for rapid growth. Proc Nutr Soc 1987; 46: 136A

14 Moran B, Persaud C, Jackson AA. Urinary excretion of 5oxoproline in severe inflammatory illness. Proc Nutr Soc 1989; 48: 75A.

15 Neuberger A. Pathways of glycine metabolism. In: Waterlow JC, Stephen JNL, eds. Nitrogen metabolism in man. London Applied Science Publishers, 1981: 253-61.

16 Jelliffe DB. Assessment of the nutritional status of the community. Geneva: World Health Organisation, 1966

17 Grimble GK, Rees RG, Patil DH, et al. Administration of fat emulsions with nutritional mixtures from the 3-liter delivery system in total parenteral nutrition. 7 Parenter Enter Nutr 1985; 9: 456-60. 
18 Grimble GK, West MFE, Acuti ABC, et al. Assessment of an automated chemiluminescence nitrogen analyser for routine use in clinical nutrition. $\mathcal{F}$ Parenter Enter Nutr 1988; 12 100-6.

19 Kopple JD, Coburn JW. Metabolic studies of low protein diets in uremia. I. Nitrogen and potassium. Medicine 1973; 52 583-95.

20 Matthews DE, Motil KJ, Rohrbaugh DK, Burke JF, Young VR, Bier DM. Measurement of leucine metabolism in man from a primed, continuous infusion of $\mathrm{L}-\left(1{ }^{-13} \mathrm{C}\right)$ leucine. Am F Physiol 1980; 238: E473-9.

21 Schneible PA, Airhart J, Low RC. Differential compartmentation of leucine for oxidation and for protein synthesis in tion of leucine for oxidation and for protein synthesis in
cultured skeletal muscle. F Biol Chem 1981; 256: 4888-94.

22 Layman DK, Wolfe RR. Sample site selection for tracer studies applying a unidirectional circulatory approach. $A m \mathcal{F}$ Physiol 1987; 253: E173-8.

23 Ford GC, Cheng KN, Halliday D. Analysis of $\left(1-{ }^{12} \mathrm{C}\right)$ leucine and $\left({ }^{13} \mathrm{C}\right) \mathrm{KIC}$ in plasma by capillary gas chromatography/ mass spectrometry in protein turnover studies. Biomed Mass Spectrom 1985; 12: 432-6.

24 Halliday D, Read WW. Mass spectrometric assay of stable isotopic enrichment for the estimation of protein turnover in man. Proc Nutr Soc 1981; 40: 321-34.

25 Pacy PJ, Read M, Halliday D. Influence of insulin on albumin and non-albumin protein fractional synthetic rates in postabsorptive type I diabetic patients. Eur $\mathcal{F}$ Clin Nutr 1990; 44: 343-9.

26 Read WW, Read MA, Rennie MJ, Griggs RC, Halliday D. Preparation of $\mathrm{CO}_{2}$ from blood and protein-bound amino acid carboxyl groups for quantification and ${ }^{13} \mathrm{C}$-isotope measurements. Biomed Mass Spectrom 1984; 11 $40-4$

27 Davies JWL. Blood volume studies. In: Belcher EH, Vetter $\mathrm{H}$, eds. Radioisotopes in medical diagnosis. London: Butterworths, 1971: 319.

28 Dykes PW. The rates of distribution and catabolism of albumin in normal subjects and in patients with cirrhosis of the liver. Clin Sci 1968; 34: 161-83.
29 Vinnars E, Bergström J, Fürst P. Comparative nitrogen balance studies with an amino-acid solution based on nutritional studies against two protein-based solutions. Acta Anaesthesiol Scand 1973; (suppl 53): 76-80.

30 Steinhardt HJ, Paleos GA, Brandl M, Fekl WL, Adibi SA Efficacy of a synthetic dipeptide mixture as the source of amino acids for total parenteral nutrition in a subhuman primate (baboon): plasma concentration, metabolic clearance, and urinary excretion of a series of dipeptides. Gastroenterology 1984; 86: 1562-9.

31 Rees RGP, Cooper TM, Beetham R, Frost PG, Silk DBA. Influence of energy and nitrogen contents of enteral diets on nitrogen balance: a double blind prospective controlled nitrogen balance: a double blind
clinical trial. Gut 1989; 30: 123-9.

32 Smith RC, Burkinshaw L, Hill GL. Optimal energy and nitrogen intake for gastroenterological patients requiring intravenous nutrition. Gastroenterology 1982; 82: 445-52.

33 Clague MB, Keir MJ, Wright PD, Johnston IDA. The effect of nutrition and trauma on whole-body protein metabolism in man. Clin Sci 1983; 65: 165-75.

34 Munro HN. Free amino acid pools and their role in regulation. In: Munro HN, ed. Mammalian protein metabolism. Vol 4 New York: Academic, 1970: 339

35 Skillman JJ, Rosenoer VM, Smith PC, Fang MS. Improved albumin synthesis in postoperative patients by amino acid albumin synthesis in postoperative patients by amino acid
infusion. N Englf Med 1976; 295: 1037-40.

36 O'Keefe SJD, Moldawer LL, Young VR, Blackburn GL. The influence of intravenous nutrition on protein dynamics following surgery. Metabolism 1981; 30: 1150-8.

37 Felig P. The glucose-alanine cycle. Metabolism 1973; 22: 179 207.

38 Bansi HW, Jürgens P, Müller G, Rostin M. Der stoffwechsel bei intravenöser applikation von nährlösungen. Insbesondere synthetisch zusammengestellter aminosäurelösungen. Klin Wochenschr 1964; 7: 332-52.

39 Adibi SA. Experimental basis for use of peptides as substrates for parenteral nutrition: a review. Metabolism 1987; 36: 1001-11. 